\title{
The genetics of lupus: a functional perspective
}

Sandra G Guerra ${ }^{1,2}$, Timothy J Vyse ${ }^{1,2}$ and Deborah S Cunninghame Graham*1,2

\begin{abstract}
Systemic lupus erythematosus (SLE) is an autoimmune disease with a strong genetic component and is characterized by chronic inflammation and the production of anti-nuclear auto-antibodies. In the era of genome-wide association studies (GWASs), elucidating the genetic factors present in SLE has been a very successful endeavor; 28 confirmed disease susceptibility loci have been mapped. In this review, we summarize the current understanding of the genetics of lupus and focus on the strongest associated risk loci found to date $\left(P<1.0 \times 10^{-8}\right)$. Although these loci account for less than $10 \%$ of the genetic heritability and therefore do not account for the bulk of the disease heritability, they do implicate important pathways, which contribute to SLE pathogenesis. Consequently, the main focus of the review is to outline the genetic variants in the known associated loci and then to explore the potential functional consequences of the associated variants. We also highlight the genetic overlap of these loci with other autoimmune diseases, which indicates common pathogenic mechanisms. The importance of developing functional assays will be discussed and each of them will be instrumental in furthering our understanding of these associated variants and loci. Finally, we indicate that performing a larger SLE GWAS and applying a more targeted set of methods, such as the ImmunoChip and nextgeneration sequencing methodology, are important for identifying additional loci and enhancing our understanding of the pathogenesis of SLE.
\end{abstract}

\section{Introduction}

Systemic lupus erythematosus (SLE) is a heterogeneous autoimmune disease characterized by hyperactive $\mathrm{T}$ and B cells, auto-antibody production, and immune complex

*Correspondence: deborah.cunninghame-graham@kcl.ac.uk

'Department of Medical and Molecular Genetics, Division of Genetics and

Molecular Medicine, King's College London, Great Maze Pond, London, SE1 9RT, UK Full list of author information is available at the end of the article
(IC) deposition [1]. SLE has a prevalence of approximately 1 in 2,500 in European populations [2] and is more frequent in those of non-European ancestry. SLE affects predominantly women (the female-to-male ratio is 9:1) of child-bearing age and is characterized by variable clinical features, including malar rash, glomerulonephritis, arthritis, and neuropsychiatric disease [3]. Although the exact etiology of lupus is not fully understood, a strong genetic link has been identified through the use of association and family studies. The heritability of SLE is approximately $66 \%$; the rates of concordance are $24 \%$ to $56 \%$ in monozygotic twins and $2 \%$ to $4 \%$ in dizygotic twins $[4,5]$.

To date, genome-wide association studies (GWASs) have identified more than 30 associated loci. In Table 1, we show the variants that have reached genome-wide significance $\left(1.0 \times 10^{-8}\right)$ in one or more GWASs, a metaanalysis, or replication studies. We have also included the $\mathrm{Fcy}$ locus, because it contains multiple associated variants, including a confirmed copy number variation (CNV) in SLE. However, these loci account for less than $10 \%$ of the genetic heritability [6].

GWASs in SLE have been useful tools for expanding the genetic understanding of SLE by identifying new loci and replicating previously associated loci. In this review, we categorize these risk loci into a number of pathways on the basis of the current understanding of the potential role for the locus in SLE. We note that the clinical heterogeneity of SLE is mirrored by the diversity of the pathways reported to contain the associated loci from the genetic studies, apoptosis, innate immune response, ubiquitination, and phagocytosis (Table 1). Therefore, this review aims to highlight the known function(s) of the associated loci and to indicate where further functional studies are needed to elucidate the pathogenic mechanisms in lupus.

\section{Contribution of apoptosis to SLE pathogenesis}

Apoptosis is a well-defined process of programmed cell death and does not immediately release the intracellular content into the extracellular environment $[7,8]$. In healthy individuals, dead or dying cells are cleared by macrophages in an inherently anti-inflammatory way. However, in patients with SLE, apoptosis has been reported to be defective and plays a role in disease 
Table 1. A summary of loci associated with systemic lupus erythematosus in one or more genome-wide association studies, a meta-analysis, and replication studies $\left(P<1.0 \times 10^{-8}\right)$

\begin{tabular}{|c|c|c|c|c|c|c|c|}
\hline Locus & Gene & Position & Variant & $\begin{array}{l}P \text { value } \\
\text { (significance) }\end{array}$ & $\begin{array}{l}\text { OR (Cl) } \\
\text { (effect size) }\end{array}$ & $\begin{array}{l}\text { Autoimmune } \\
\text { disease } \\
\text { associations }\end{array}$ & Function \\
\hline ITGAM ${ }^{a}$ & Intergrin alpha M & 16p11.2 (intronic) & rs9888739 (T) & $1.61 \times 10^{-23}$ & $1.62(1.47-1.78)$ & & Phagocytosis \\
\hline$F \subset \gamma R$ & Fcy receptors & $\begin{array}{l}\text { Multiple } \\
\text { (see text) }\end{array}$ & $\begin{array}{l}\text { Multiple } \\
\text { (see text) }\end{array}$ & $\begin{array}{l}\text { Multiple } \\
\text { (see text) }\end{array}$ & $\begin{array}{l}\text { Multiple } \\
\text { (see text) }\end{array}$ & UC & Phagocytosis \\
\hline PRDM1-ATG5 ${ }^{\mathrm{b}}$ & $\begin{array}{l}\text { PR domain zinc finger } \\
\text { protein } 1 \text { - autophagy- } \\
\text { related } 5 \text { homolog }\end{array}$ & $\begin{array}{l}6 \mathrm{q} 21-\mathrm{q} 22.1 \\
\text { (intergenic) }\end{array}$ & rs548234 (G) & $5.18 \times 10^{-12}$ & $1.25(1.17-1.33)$ & & $\begin{array}{l}\text { Autophagy and } \\
\text { B-cell differentiation }\end{array}$ \\
\hline TNFAIP3 ${ }^{b}$ & $\begin{array}{l}\text { Tumor necrosis factor- } \\
\text { alpha-induced protein }\end{array}$ & $\begin{array}{l}6 \mathrm{q} 23 \\
\text { (exonic) }\end{array}$ & rs2230926 (C) & $1.37 \times 10^{-17}$ & $1.72(1.52-1.94)$ & $\begin{array}{l}\text { RA, CelD, UC, } \\
\text { and PS }\end{array}$ & Ubiquitination \\
\hline TNIP1e & $\begin{array}{l}\text { TNFAIP3-interacting } \\
\text { protein } 1\end{array}$ & $\begin{array}{l}5 q 32-q 33.1 \\
\text { (intronic) }\end{array}$ & rs7708392 (C) & $3.8 \times 10^{-13}$ & $1.27(1.10-1.35)$ & PS & \\
\hline$U B E 2 L 3^{b}$ & $\begin{array}{l}\text { Ubiquitin-conjugating } \\
\text { enzyme E2L } 3\end{array}$ & $\begin{array}{l}22 q 11.2-q 13.1 \\
\text { (upstream) }\end{array}$ & rs463426 (G) & $1.48 \times 10^{-16}$ & $0.78(0.74-0.83)$ & $\begin{array}{l}\text { CD, RA, and } \\
\text { CelD }\end{array}$ & \\
\hline$E T S 1^{\mathrm{b}}$ & $\begin{array}{l}\text { V-ETS avian } \\
\text { erythroblastosis } \\
\text { virus E26 oncogene } \\
\text { homolog } 1\end{array}$ & $\begin{array}{l}11 \mathrm{q} 23.3 \\
\text { (downstream) }\end{array}$ & rs6590330 (A) & $1.77 \times 10^{-25}$ & $1.37(1.29-1.45)$ & RA & $\begin{array}{l}\text { Lymphocyte } \\
\text { development and } \\
\text { activation }\end{array}$ \\
\hline$\left.I K Z F\right|^{b}$ & $\begin{array}{l}\text { IKAROS family zinc } \\
\text { finger } 1\end{array}$ & $\begin{array}{l}7 p 12 \\
\text { (upstream) }\end{array}$ & rs4917014 (C) & $2.75 \times 10^{-23}$ & $1.23(1.03-1.42)$ & & \\
\hline CD44d & CD44 & $\begin{array}{l}11 \mathrm{p} 13 \\
\text { (upstream) }\end{array}$ & rs507230 & $3.98 \times 10^{-12}$ & $0.71(0.63-0.79)$ & & \\
\hline BANKK & $\begin{array}{l}\text { B-cell scaffold protein } \\
\text { with ankyrin repeats } 1\end{array}$ & $\begin{array}{l}4 \mathrm{q} 22-\mathrm{q} 24 \\
\text { (exonic) }\end{array}$ & rs10516487 (G) & $3.7 \times 10^{-10}$ & $1.38(1.25-1.53)$ & RA & $\begin{array}{l}\text { B-cell activation and } \\
\text { signaling }\end{array}$ \\
\hline$B L K^{\circ}$ & $\begin{array}{l}\text { B lymphoid tyrosine } \\
\text { kinase }\end{array}$ & $\begin{array}{l}\text { 8p23-p22 } \\
\text { (upstream) }\end{array}$ & rs7812879 (A) & $2.09 \times 10^{-24}$ & $0.69(0.64-0.74)$ & RA & \\
\hline$\angle Y N^{a}$ & $\begin{array}{l}\text { V-yes-1 Yamaguchi } \\
\text { sarcoma viral-related } \\
\text { oncogene homolog }\end{array}$ & $\begin{array}{l}8 \mathrm{q} 13 \\
\text { (intronic) }\end{array}$ & rs7829816 (C) & $5.40 \times 10^{-9}$ & $0.77(0.70-0.84)$ & & \\
\hline RasGRP3 ${ }^{b}$ & $\begin{array}{l}\text { RAS guanyl releasing } \\
\text { protein } 3 \text { (calcium and } \\
\text { DAG-regulated) }\end{array}$ & $\begin{array}{l}2 \mathrm{p} 25.1-\mathrm{p} 24.1 \\
\text { (intronic) }\end{array}$ & rs13385731 (G) & $1.25 \times 10^{-15}$ & $0.70(0.64-0.76)$ & & \\
\hline NCF $2^{f}$ & $\begin{array}{l}\text { Neutrophil cytosolic } \\
\text { factor } 2\end{array}$ & $\begin{array}{l}1 \mathrm{q} 25 \\
\text { (intronic) }\end{array}$ & rs10911363 (T) & $2.87 \times 10^{-11}$ & $1.18(1.10-1.30)$ & & \\
\hline STAT $4^{b}$ & $\begin{array}{l}\text { Signal transducer } \\
\text { and activator of } \\
\text { transcription } 4\end{array}$ & $\begin{array}{l}2 q 32.2-q 32.3 \\
\text { (intronic) }\end{array}$ & rs7574865 (A) & $5.17 \times 10^{-42}$ & $1.51(1.43-1.61)$ & $\begin{array}{l}\text { RA, IBD, T1D, } \\
\text { and Sjögren's } \\
\text { syndrome }\end{array}$ & $\begin{array}{l}\text { T-cell development } \\
\text { and signaling }\end{array}$ \\
\hline PTPN22 & $\begin{array}{l}\text { Protein tyrosine } \\
\text { phosphatase non- } \\
\text { receptor type } 22\end{array}$ & $\begin{array}{l}1 \mathrm{p} 13 \\
\text { (exonic) }\end{array}$ & rs2476601 (A) & $3.4 \times 10^{-12}$ & $1.35(1.24-1.47)$ & $\begin{array}{l}\text { T1D and Graves' } \\
\text { disease }\end{array}$ & \\
\hline TNFSF $4^{\mathrm{b}}$ & $\begin{array}{l}\text { Tumor necrosis factor } \\
\text { (ligand) superfamily } \\
\text { member } 4\end{array}$ & $\begin{array}{l}\text { 1q25 } \\
\text { (upstream) }\end{array}$ & rs2205960 (A) & $2.5 \times 10^{-32}$ & $1.46(1.37-1.56)$ & & \\
\hline$H L A-D R B 1^{e}$ & $\begin{array}{l}\text { HLA class II } \\
\text { histocompatibility } \\
\text { antigen }\end{array}$ & $\begin{array}{l}\text { 6p21.3 } \\
\text { (downstream) }\end{array}$ & rs3135394 (G) & $2.0 \times 10^{-60}$ & $1.98(1.84-2.14)$ & $\begin{array}{l}\text { T1D, RA, CelD, } \\
\text { IBD, and CD }\end{array}$ & $\begin{array}{l}\text { Antigen } \\
\text { presentation }\end{array}$ \\
\hline$S L C 15 A 4^{b}$ & $\begin{array}{l}\text { Solute carrier family } 15 \text {, } \\
\text { member } 4\end{array}$ & $\begin{array}{l}12 \mathrm{q} 24.32 \\
\text { (exonic) }\end{array}$ & rs $10847697(A)$ & $3.54 \times 10^{-11}$ & $1.26(1.17-1.34)$ & & \\
\hline IRF5 & $\begin{array}{l}\text { Interferon regulatory } \\
\text { factor } 5\end{array}$ & $\begin{array}{l}7 q 32 \\
\text { ( } 3^{\prime} \text { untranslated } \\
\text { region) }\end{array}$ & rs2070197 (C) & $5.8 \times 10^{-24}$ & $1.88(1.78-1.95)$ & $\begin{array}{l}\text { Rheumatic } \\
\text { disease and RA }\end{array}$ & $\begin{array}{l}\text { Interferon regulation } \\
\text { and production }\end{array}$ \\
\hline$I R F 7^{a}$ & $\begin{array}{l}\text { Interferon regulatory } \\
\text { factor } 7\end{array}$ & $\begin{array}{l}11 \mathrm{p} 15.5 \\
\text { (downstream) }\end{array}$ & rs4963128 (T) & $3.0 \times 10^{-10}$ & $0.78(0.73-0.85)$ & T1D & \\
\hline
\end{tabular}


Table 1. Continued

\begin{tabular}{|c|c|c|c|c|c|c|c|}
\hline Locus & Gene & Position & Variant & $\begin{array}{l}P \text { value } \\
\text { (significance) }\end{array}$ & $\begin{array}{l}\text { OR (CI) } \\
\text { (effect size) }\end{array}$ & $\begin{array}{l}\text { Autoimmune } \\
\text { disease } \\
\text { associations }\end{array}$ & Function \\
\hline IRF8 & $\begin{array}{l}\text { Interferon regulatory } \\
\text { factor } 8\end{array}$ & $\begin{array}{l}\text { 16q24.1 } \\
\text { (downstream) }\end{array}$ & rs2280381 (A) & $1.24 \times 10^{-8}$ & $1.17(1.10-1.24)$ & UC and MS & \\
\hline$|F| H 7^{\dagger}$ & $\begin{array}{l}\text { Interferon-induced } \\
\text { helicase C domain- } \\
\text { containing protein } 1\end{array}$ & $\begin{array}{l}2 q 24 \\
\text { (exonic) }\end{array}$ & rs1990760 (T) & $1.63 \times 10^{-8}$ & $1.23(1.09-1.39)$ & & \\
\hline TYK $2^{f}$ & Tyrosine kinase 2 & $\begin{array}{l}\text { 19p13.2 } \\
\text { (intronic) }\end{array}$ & rs280519 (A) & $3.88 \times 10^{-8}$ & $1.29(1.15-1.47)$ & MS & \\
\hline $\begin{array}{l}\text { LRRC18- } \\
\text { WDFY4 }\end{array}$ & $\begin{array}{l}\text { Leucine-rich repeat } \\
\text { containing } 18-W D \\
\text { repeat and FYVE } \\
\text { domain-containing } \\
\text { protein } 4\end{array}$ & $\begin{array}{l}\text { 10q11.22-q11.23 } \\
\text { (intergenic) }\end{array}$ & rs1913517 (A) & $7.22 \times 10^{-12}$ & $1.24(1.17-1.32)$ & & Unknown function \\
\hline$P X K^{\mathrm{a}}$ & $\begin{array}{l}\text { PX domain containing } \\
\text { serine/threonine kinase }\end{array}$ & $\begin{array}{l}3 p 14.3 \\
\text { (intronic) }\end{array}$ & rs6445975 (C) & $7.10 \times 10^{-9}$ & $1.25(1.16-1.35)$ & RA & \\
\hline$J A Z F 7^{e}$ & $\begin{array}{l}\text { Juxtaposed with } \\
\text { another zinc finger } \\
\text { gene } 1\end{array}$ & $\begin{array}{l}\text { 7p15 } \\
\text { (intronic) }\end{array}$ & rs849142(T) & $1.5 \times 10^{-9}$ & $1.19(1.13-1.26)$ & & \\
\hline UHRF1BP1e & UHRF-binding protein 1 & $\begin{array}{l}6 q 23 \\
\text { (exonic) }\end{array}$ & rs11755393 (G) & $2.2 \times 10^{-8}$ & $1.17(1.10-1.24)$ & & \\
\hline$X K R 6^{\mathrm{a}}$ & $\begin{array}{l}\text { XK, Kell blood group } \\
\text { complex subunit- } \\
\text { related family, } \\
\text { member } 6\end{array}$ & $\begin{array}{l}8 p 23.1 \\
\text { (intronic) }\end{array}$ & rs6985109 (G) & $2.51 \times 10^{-11}$ & $1.23(1.16-1.30)$ & & \\
\hline
\end{tabular}

Odds ratios (ORs) and confidence intervals $(\mathrm{Cls})$ are noted with the primary function of each locus. The genome-wide association studies from which this table was generated were conducted by ${ }^{2}$ Harley and colleagues [95] (1,846 systemic lupus erythematosus (SLE) women cases and 1,825 controls), ${ }^{b} \mathrm{Han}$ and colleagues [53] (1,047 Han Chinese cases and 1,205 controls), and 'Kozyrev and colleagues [59] (279 Swedish SLE cases and 515 controls). The meta-analysis study was conducted by dRamos and colleagues [58] (939 Caucasian cases and 3,398 controls). The replication studies were conducted by Han and colleagues [53] (3,152 Han Chinese cases and 7,050 controls), e Gateva and colleagues [6] (1,963 cases and 4,329 controls), and fCunninghame Graham and colleagues [69] (870 UK SLE cases and 5,551 controls). All loci that have been reported to be associated with other autoimmune diseases - Crohn's disease (CD), celiac disease (CeID), irritable bowel syndrome (IBD), multiple sclerosis (MS), psoriasis (PS), rheumatoid arthritis (RA), type 1 diabetes (T1D), and ulcerative colitis (UC) - are also stated [58].

manifestation [9]. Patients with SLE demonstrate defective clearance of apoptotic cells, which evokes a secondary transition into necrotic cell death [10]. During apoptosis, cells shrink and change morphology by engulfing self-antigens, forming membrane-bound blebs that are exposed on the cell surface. Once engulfed, these blebs carry on their surface intracellular proteins, which can act as a source of auto-antigens, a tendency that is enhanced if clearance is defective $[11,12]$. With defective clearance of apoptotic blebs, cells undergo secondary necrosis, releasing nuclear auto-antigens [13]. This process triggers the production of inflammatory cytokines and interferon-alpha (IFN $\alpha)$ [10], promoting lymphocyte loss of self-tolerance, auto-antibody production, and IC deposition. The ICs can bind low-affinity FcyRIIa, expressed on plasmacytoid dendritic cells (pDCs). After endocytosis of the ICs, Toll-like receptor $7 / 9$ (TLR7/9) is activated through the DNA/RNA presented by IC [14] and this in turn stimulates the production of IFN by pDCs (Figure 1). This production of IFN propagates chronic inflammation and loss of tolerance, both of which are hallmarks of SLE. It has also been reported that patients with SLE have an increased rate of lymphocyte apoptosis [15], which is possibly due to increased activation of these cells. Mutations in a number of loci associated with SLE have been reported to propagate defective clearance of apoptotic cells and increased apoptosis.

\section{ITGAM}

ITGAM encodes the $\alpha$-chain of $\alpha \mathrm{M} \beta 2$-intergin $(C D 11 b)$ [16] and plays a role in phagocytosis and leukocyte adhesion [17]. GWASs have reported that variants at this locus are associated with SLE, and single-nucleotide polymorphism (SNP) rs9888739 showed the strongest association $\left(P=1.61 \times 10^{-23}\right.$, odds ratio $\left.(\mathrm{OR})=1.62\right)$. However, a trans-ancestral study in European-Americans and African-Americans [18] indicated the causal variant as rs1143679, which has been reported to cause two functional changes in ITGAM. The first of these functional changes is an amino acid mutation at $\mathrm{R} 77 \mathrm{H}$ (Arg-His) which modifies the tertiary and quaternary structures of the $\alpha \mathrm{M} \beta 2$ ligand-binding domain [18]. $\alpha M \beta 2$-integrin interacts with a number of ligands such as 


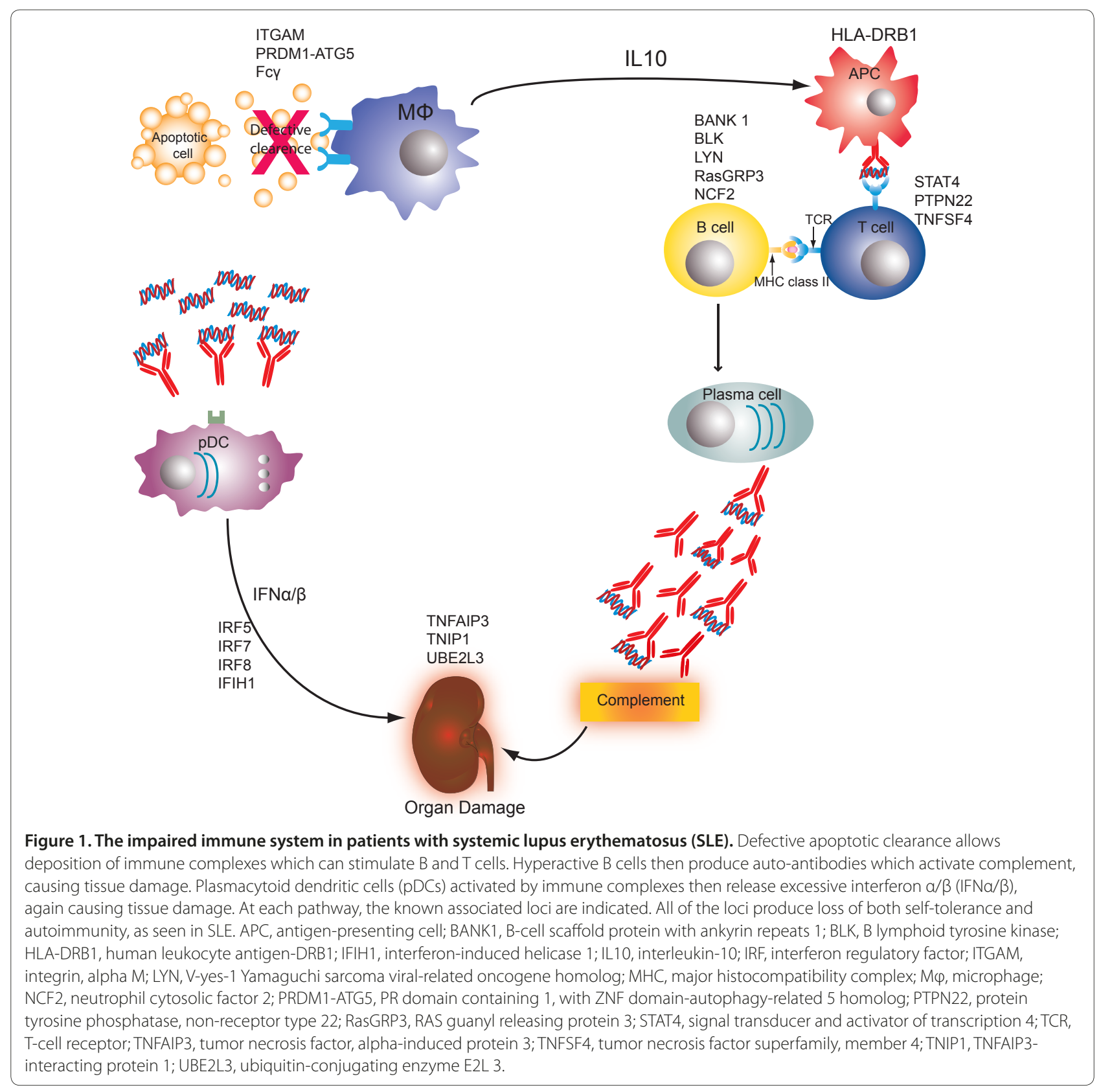

intracellular adhesion molecule 1 (ICAM-1) and the complement $\mathrm{C} 3$ degradation product, $\mathrm{C} 3 \mathrm{bi}$; these ligands play a role in leukocyte activation, migration, and phagocytosis [16]. Variants in the $\alpha \mathrm{M} \beta 2$ ligand-binding domain may alter binding affinity, hence leukocyte trafficking, phagocytosis [16], and IC clearing [19]. The second functional change is with rs1143679, which impairs the phagocytosis of C3bi-coated particles [20] and propagates the deficient clearance of ICs and increased inflammation [20]. However, the exact mechanism of how both of these variants influence the pathogenesis of SLE warrants further investigation.

\section{Fcy receptors}

The FCGR genes encode diverse $\mathrm{Fc \gamma}$ receptors that recognize the Fc portion of immunoglobulin G (IgG) molecules. Several missense polymorphisms in FCGR2A, FCGR2B, and FCGR3A [21-23] are associated with SLE. Three of the five FCGR genes (FCGR3A, FCGR2C, and $F C G R 3 B$ ) have been reported to show CNV [24] and expression of $\mathrm{Fc} \gamma$ receptors on the cell surface is dependent on the number of copies expressed $[25,26]$. A CNV that resulted in a reduced number of FCGR3B molecules expressed on the cell surface of neutrophils is associated with SLE. The exact mechanism by which the CNV 
incorporating $F C G R 3 B$ promotes disease is not fully established, although reduced binding of ICs by neutrophils is a possible mechanism.

\section{The role of ubiquitination in SLE}

Ubiquitination is still an incompletely understood biochemical process by which proteins are post-translationally modified through the addition of single ubiquitin molecules or polyubiquitin chains. During ubiquitination, proteins may be tagged for protelolytic degradation by the proteosome. Ubiquitination has also been reported to regulate transcription factors and intracellular kinase activity [27]. Genes that encode these different components of the protein modification system have been reported to be associated with SLE.

\section{TNFAIP3 and TNIP1}

TNFAIP3 encodes the ubiquitin-editing enzyme A20 $[28,29]$, which alters ubiquitin patterns, which then alter targeting for proteosome degradation and termination of nuclear factor-kappa-B (NF-kB)-derived pro-inflammatory responses. This occurs through the ubiquitination of IKK $\gamma$ and phosphorylation of IKB $\alpha[30,31]$, facilitating the release of NF- $k B$ (Figure 2). A20 is a key regulator of NF- $k B$ through ubiquitin modifications of receptorinteracting protein kinase (RIP) and tumor necrosis factor receptor-associated kinase 6 (TRAF6) [32]. Multiple associations have been found in TNFAIP3 in a range of autoimmune diseases [28]; of these associations, rs2230926 has shown the strongest significance $\left(P=1.37 \times 10^{-17}, \mathrm{OR}=1.72\right)$ in SLE. This non-synonymous SNP [33] causes an amino acid change from a PheCys. This amino acid change propagates A20 protein to be less effective at inhibiting tumor necrosis factor (TNF)-induced NF- $\mathrm{kB}$ activity [34]. Variants at this locus could potentially lead to reduced inhibitory activity of NF- $\mathrm{kB}$ and reduced expression of A20.

Owing to increased NF-kB signaling, Tnfaip $3^{-/-}$mice develop spontaneous inflammation and lymphocyte cell death [35]. This shows the importance of TNFAIP3 in NF$\kappa B$ regulation through the ubiquitination of adaptors such as RIP [35]. Therefore, it can be seen that TNFAIP3 is an important locus that contributes to SLE pathogenesis through its downregulation. The downregulation of TNFAIP3 facilitates hyperactive NF- $\mathrm{kB}$ signaling, chronic inflammation, and reduced apoptosis, all characteristics of SLE.

TNIP1, an adaptor protein that binds to A20, has also been reported to be associated with SLE. TNIP1 is expressed on lymphocytes and its expression is induced by NF-kB [36]. However, overexpression of TNIP1 inhibits NF- $\mathrm{kB}$ activation by TNF [37]. Variants in TNIP1 could potentially play a role in negatively regulating the NF-kB pathway [38]. SNP rs7708392 has been reported to play a role in TNIP1 splicing, rendering the inhibition

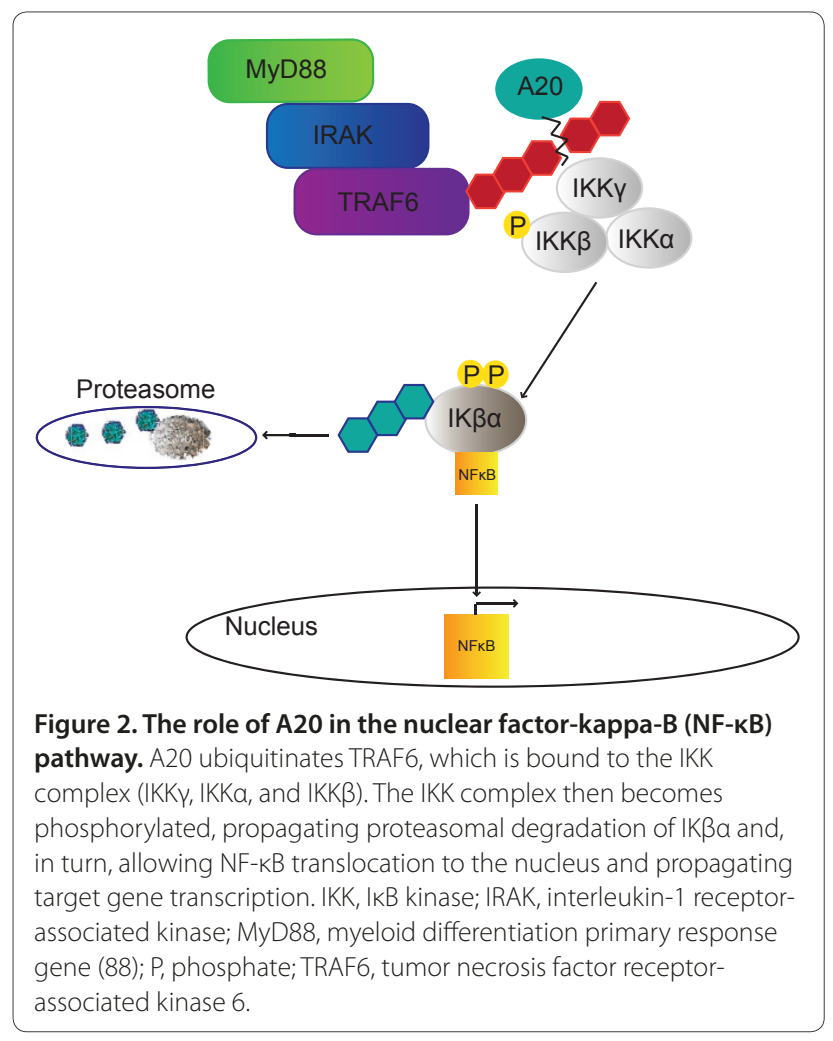

of the NF-kB pathway less effective. This would propagate pro-inflammatory responses and chronic inflammation. This variant has been shown to be associated with Caucasian and Asian populations [36].

\section{UBE2L3}

$\triangle B E 2 L 3$ is a ubiquitin-carrier enzyme gene and is expressed widely on all lymphocytes [39]. It plays a key role in the maturation of transcription factors (for example, p53 and p105, the latter of which is an NF-kB precursor) $[40,41]$. This enzyme regulates IFN through TLR7/9 [42,43]. The exact mechanism of UBE2L3 is still not fully understood, but variants in this locus have been shown to be associated with SLE (rs463426, $\left.P=1.48 \times 10^{-16}, \mathrm{OR}=0.78\right)$.

\section{Abnormalities of lymphocyte development in SLE}

SLE is associated with multiple dysfunctions in many lymphocyte subsets. SLE T cells have been reported to show inappropriate tissue homing, increased secretion of pro-inflammatory cytokines [44], and activation of both dendritic cells (DCs) and B cells [45]. A number of loci have been found to be associated with lymphocyte differentiation and SLE, as described below.

\section{ETS1 and IKZF1}

ETS1 and IKZF1 are transcription factors that regulate lymphocyte differentiation and lymphocyte development 
$[46,47]$. ETS1 has been reported as a negative regulator of B-cell differentiation and T helper $17\left(\mathrm{Th}_{17}\right)$ cell proliferation [48]. Patients with SLE demonstrate a reduced expression of ETS1, which may contribute to abnormal B-cell differentiation into immunoglobulin-secreting plasma cells and an increased number of $\mathrm{Th}_{17}$ cells [49-51]. While having increased proliferation of $\mathrm{Th}_{17}$ cells causes increased inflammation through the secretion of interleukin-17 (IL-17), ETS1-deficient Th cells secrete higher amounts of anti-inflammatory cytokine IL-10 [52]. Interestingly, these ETS1-deficient $\mathrm{Th}_{1}$ cells have reduced secretion of IL-2, which is a potent $T_{17}$ inhibitor [52]. The top associated variant at this locus, rs6590330 $\left(P=1.77 \times 10^{-25}, \mathrm{OR}=1.37\right)$, could potentially play a role in decreasing ETS1 expression.

Patients with SLE have also been reported to express low IKZF1 levels in peripheral blood [48]. The strongest association found at this locus is rs4917014 $\left(P=2.75 \times 10^{-23}, \mathrm{OR}=1.23\right)$ [53], which may play a role in downregulating IKZF1 expression. This reduced level of expression contributes to SLE pathogenesis through interactions with other genes; for example, IKZF1 has been reported to play a role in trans-activating STAT4, a confirmed risk locus in SLE [54]. IKZF1 is important for lymphocyte differentiation [55] and regulation of selftolerance through B-cell receptor (BCR) signaling [56]. Downregulation of this locus would therefore promote loss of self-tolerance, a hallmark of SLE.

\section{Inappropriate B-cell physiology in SLE}

Hyperactive B cells play an important role in the pathogenesis of SLE. With the production of auto-antibodies and prolonged cell life, B-cell regulation is important in the maintenance of immune balance. $B$ cells of patients with SLE have been shown to present auto-antigens, induce $\mathrm{CD} 4^{+} \mathrm{T}$ helper cells $\left(\mathrm{Th}_{1} / \mathrm{Th}_{2}\right)$, inhibit $\mathrm{T}$ regulatory cells, and secrete pro-inflammatory cytokines [57]. A number of key loci have been reported to be associated with SLE and are described below.

\section{$B A N K 1, B L K$, and $L Y N$}

The gene products of $B A N K 1, B L K$, and $L Y N$ operate in the BCR signaling pathway and have been reported to be associated with SLE [58], which together attest to the importance of this pathway in disease pathogenesis. rs10516487, located in the BANK1-binding region [59], has shown the strongest association with SLE $\left(P=3.1 \times 10^{-10}, \mathrm{OR}=1.38\right)$. After B-cell activation, $B A N K 1$ becomes tyrosine-phosphorylated, resulting in phosphorylation of type 1 inositol-1,2,4-triphosphate (IP(3)R). This phosphorylation event serves to augment calcium mobilization and hence B-cell activation [60]. The associated variant at BANK1 increases its expression by influencing splicing efficiency, creating a splicing enhancer [59]. The expression increase propagates stronger binding affinity between BANK1 and IP(3)R, resulting in hyper-responsiveness [61]. Cells expressing the risk allele of this variant also have higher protein levels, which can sustain BCR signaling and hyperactive B cells, as shown in SLE [59].

Associated allelic variants in BLK (rs7812879, $\left.P=2.09 \times 10^{-24}, \mathrm{OR}=0.69\right)$ and $L Y N(\mathrm{rs} 7829819$, $P=5.40 \times 10^{-9}, \mathrm{OR}=0.77$ ), in comparison with $B A N K 1$, have been shown to decrease their respective expressions [61,62]. LYN kinase mediates inhibitory signals from CD22, which modulates the B-cell activation threshold [63]. Downregulation of $L Y N$ causes hyper-responsiveness of BCR stimulation, triggering autoimmunity [64] as shown in $\mathrm{Lyn}^{-/-}$mice [65]. Compared with $B L K$, which affects pre-BCR signaling, active $B L K$ enhances $\mathrm{BCR}$ responsiveness [66]. $B l k^{-1-}$ mice have shown no phenotype [67]; thus, an interaction with BANK1 could potentially explain the association with SLE [61]. As $L Y N$ and $B L K$ share similarities of genomic structure [64], it is believed that, in BCR signaling, $B L K$ plays a role similar to that of $L Y N$.

\section{RasGRP3}

RasGRP3 regulates Ras-ERK signaling, which is crucial in lymphocyte development and activity [68], and is involved in B-cell proliferation and immunoglobulin production [53]. rs13385731 $\left(P=1.25 \times 10^{-15}\right.$, OR $\left.=0.70\right)$ at the RasGRP3 locus has been reported to be associated with SLE and may cause an underexpression of RasGRP3, which blocks its inhibitory role in B-cell proliferation.

\section{NCF2}

NCF2 is a cytosolic subunit of NADPH oxidase, which is expressed on B cells [69]. It is thought to play a role in the increased production and release of free radicals, propagating B-cell activation. $\operatorname{rs} 10911363\left(P=2.87 \times 10^{-11}\right.$, $\mathrm{OR}=1.18)$ has been shown to have reached genomewide significance in SLE [69] and could play a role in increased NCF2 expression in patients with SLE.

\section{Dysregulation of T cells in SLE}

Patients with SLE demonstrate an increased number of $\mathrm{CD}^{+} \mathrm{CD} 4{ }^{-} \mathrm{CD} 8^{-} \mathrm{T}$ cells and $\mathrm{Th}_{17}$ cells and a variable effect on $\mathrm{T}$ regulatory cells [44]. These T-cell subsets together lead to increased inflammation, B-cell interaction, and tissue damage [45]. SLE T cells engage the CD3-TCR faster and earlier, leading to increased signaling and intracellular calcium levels. These increased calcium levels may lead to increased expression of CD40L, increasing transcription of cAMP-responsive element modulator (CREM), which would produce hyperactive $\mathrm{T}$ cells [70]. However, data on $\mathrm{T}$ regulatory cell expression in SLE have been variable. Some reports 
suggest that $\mathrm{T}$ regulatory cells, such as $\mathrm{CD} 4{ }^{+} \mathrm{CD} 25^{+} \mathrm{T}$ cells, are deficient in SLE [71]. However, others report enrichment for this cell type [72,73], perhaps relating to heterogeneity in the definitions of regulatory cells using cell-surface markers. It has also been reported that SLE T cells, compared with control $\mathrm{T}$ cells, undergo an increased rate of apoptosis, which again will contribute to SLE pathogenesis. As described below, there are a number of associated loci whose gene products play a key role in T-cell development and TCR signaling and have been reported to be associated with SLE.

\section{STAT4}

STAT4 is a $\mathrm{Th}_{1}$ transcription factor that has been reported to mediate $\mathrm{Th}_{1} \mathrm{~T}$-cell response, $\mathrm{Th}_{1}$ cytokines, IL-12 and IL-23 [74,75], and IFN $\gamma$ signaling [76,77]. rs7574865 has been reported to have the strongest association with $\operatorname{SLE}\left(P=5.17 \times 10^{-42}, \mathrm{OR}=1.51\right)$ and has also been described for other autoimmune diseases such as rheumatoid arthritis (RA) [74], Sjögren's syndrome [78], inflammatory bowel disease, and type 1 diabetes (T1D) [79]. rs7574865 has been described as being associated with many SLE clinical features, such as lupus nephritis [80]. STAT4 propagates a Th $\mathrm{T}$-cell response, increasing IFN $\gamma$ release [81]. As seen in Figure 1, this influx of IFN $\gamma$ would target organs such as the kidneys, propagating further IFN $\gamma$ release and chronic inflammation. rs7574865 may act to increase STAT4 expression and hence IFN $\gamma$ production. Further reports have shown that other associated variants, such as rs7582694 (intronic), show overexpression of the risk allele $(C)$ in mesenchymal cells but not in B cells [82]. This STAT4 risk allele was also reported to be overexpressed in cells carrying the risk haplotype in comparison with cells not carrying this haplotype [82].

\section{PTPN22}

PTPN22 encodes the lymphoid tyrosine phosphate protein, LYP, which is involved in the downregulation of T-cell activation through the interaction with cytoplasmic tyrosine kinase (CSK) and suppression of T regulatory cells [83]. rs2476601 $\left(P=3.4 \times 10^{-12}\right.$, OR $=$ 1.35) has been reported to be associated with SLE and also with T1D and RA [84]. Furthermore, a transancestral study has shown that rs2476601 is associated with SLE in Europeans, Hispanics, and AfricanAmericans [85]. The associated variant causes the amino acid change of Arg-Try, preventing PTPN22 interaction with CSK $[86,87]$. However, the experimental evidence suggests that rs2476601 reduces TCR signaling [88]. Furthermore, PTPN22 expressing the associated risk allele (A) has been reported to bind CSK less effectively than those expressing the $G$ allele, producing hyperresponsive $\mathrm{T}$ cells [85]. Therefore, the current experimental evidence does not give us the full understanding of PTPN22 function and warrants further investigation.

\section{TNFSF4 (OX40L)}

TNFSF4 is expressed on the surface of antigen-presenting cells (APCs), B cells, and macrophages, and its unique ligand CD123 (OX40) is expressed on activated CD4+ and $\mathrm{CD}^{+} \mathrm{T}$ cells [89]. The strongest association in TNFSF4 is with the upstream variant $\mathrm{rs} 2205960\left(P=2.5 \times 10^{-32}\right.$, $\mathrm{OR}=1.46)$, and protective and risk haplotypes that carry alternate alleles of rs2205960 have been observed [90]. The risk haplotype has been reported to be associated with increased TNFSF4 transcript levels [91,92]. This increased expression of $O X 40 \mathrm{~L}$ promotes $\mathrm{OX} 40 / \mathrm{OX} 40 \mathrm{~L}$ interactions and increases the co-stimulatory signal between APCs and T cells, and this in turn increases Tcell survival and thereby propagates autoimmunity. OX4OL has been shown in vitro to inhibit the generation of IL-10-producing $\mathrm{T}$ regulatory cells needed for tolerance, and it is known that mutations in this pathway cause loss of tolerance and autoimmunity [93].

\section{Defective antigen presentation in SLE HLA-DRB1/MHC}

The major histocompatibility complex $(M H C)$ region has been shown to exert the strongest genetic association and effect in SLE to date; the top association was found at HLA-DRB1 $\left(P=2.0 \times 10^{-60}, \mathrm{OR}=1.98\right)$. Studies examining the association with HLA class II have implicated both HLA-DRB1*03:01 and HLA-DRB1*15:01 [94] in SLE. The $M H C$ is composed of 250 genes subdivided into three classes (I, II, and III) with a strong linkage disequilibrium (LD) spanning the region. There appear to be multiple independent signals at the $M H C$ in SLE, accounting for the overall strength of the association seen with the region. One paper reported a $180-\mathrm{kb}$ region of class II, spanning $H L A-D R B 1, H L A-D Q A 1$, and $H L A-$ $D Q B$ [95], whereas the second signal was found in a marker of the class III gene SKIV2L. Other immunologically relevant genes such as complement $C 4 A$ and $C 4 B$ are also in this region of $M H C$. The strong $\mathrm{LD}$ covering the extended $\mathrm{MHC}$ region makes it difficult to identify whether the association arises from the associated variants currently identified or from variants within this LD region. For this reason, further fine mapping of the region is needed and the region may also benefit from trans-ancestral mapping [96].

\section{The interferon signature and its regulation in SLE}

More than half of patients with SLE show a dysregulation in the expression of genes in the IFN pathway [97]. The type I IFNs are potent cytokines (IFN $\alpha$ and IFN $\beta$ ) and also mediate the $T_{1}$ response, sustain activated $\mathrm{T}$ cells, 
sustain B-cell survival, and lower the B-cell activation threshold [98]. These responses propagate pro-inflammatory cytokines, contributing to chronic inflammation and tissue damage [14]. IFN also acts as a bridging mechanism between the innate and adaptive immune systems. However, it is unclear whether elevated IFN is the causal effect of SLE or whether it further propagates disease intensity. Given the genetic role of IRF5 and a number of other genes in the IFN pathway, it is likely that IFN exerts a pathway effect in the pathogenesis of disease.

\section{IRF5, IRF7, and IRF8}

$I R F 5$, IRF7, and IRF8 are transcription factors that play a role in type 1 IFN signaling and immune cell development [99]. SNPs in IRF5, IRF7, and IRF8 $\left(P=5.8 \times 10^{-24}, \mathrm{OR}=\right.$ $1.88 ; P=3.0 \times 10^{-10}, \mathrm{OR}=0.78$; and $P=1.24 \times 10^{-8}$, $\mathrm{OR}=$ 1.17 , respectively) (as shown in Table 1) have been shown to be associated with increased risk of SLE [98]. These variants have been shown to increase the levels of IRF5, $I R F 7$, and IRF8 transcript and protein expressions [100]. Of these three loci, IRF5 exhibits the largest effect. An IRF5 risk haplotype has been observed and carries multiple mutations, including rs2004640, which has been reported to create a novel splicing variant. Another variant found at the 3' untranslated region, rs10954213, has been reported to create a more functional polyadenlyation site, which creates a more stable transcript [101]. Variants in the IRF5 locus influence alternatively spliced transcripts, which alter or prolong IRF5 expression. Hence, increased expression of IRF5 propagates increased IFN $\alpha$ production. Little is reported for IRF7 and IRF8; therefore, these loci warrant further investigation to determine the functional consequences of the associated variants.

\section{IFIH1}

IFIH1 is a DEAD box helicase that senses intracellular RNA and induces IFN (type 1) activation [102]. Variants at this locus have been associated with other autoimmune diseases such as T1D [103], autoimmune thyroid disease [104], and psoriasis [105]. The top associated SNP in SLE is rs1990760 $\left(P=1.63 \times 10^{-8}, \mathrm{OR}=1.23\right)$, which has been shown to increase expression of IFIH1. This increased expression could contribute to an IFN cascade initiated by nucleic acids.

\section{TYK2}

TYK2 plays an important role in the pro-inflammatory immune response, being involved in cytokine signaling and the phosphorylation of IFN receptors, triggering a type 1 IFN response [69]. Variants in TYK2 have been reported to increase type 1 IFN gene expression [106] and deregulate the $T h_{1} / T h_{17}$ response. $T h_{17}$ cells are pro-inflammatory, and their differentiation is dependent on IL-6 and transforming growth factor-beta (TGF $\beta$ ), both of which are cytokines that are regulated by TYK2 [107]. The top associated SNP in SLE, rs280519 $\left(P=3.88 \times 10^{-8}\right)$, has been shown to play a role in increasing gene expression and IFN production. Variants propagating increased TYK2 function have also been reported to lead to a pro-inflammatory phenotype with increased levels of $T h_{1} / T_{17}$ cells [107]. Multiple variants in TYK2 have been reported to be associated with other autoimmune and inflammatory diseases [108].

\section{Known intergenic interactions in SLE}

From the published GWASs, we are able to identify associated variants for SLE in intergenic regions in addition to those in coding regions of genes. When intergenic loci are identified, it is important to ascertain the functional consequence of the variant on the neighboring genes. Indeed, until a molecular mechanism is fully elucidated, one cannot conclude that any associated allele will primarily exert its pathological effect by influencing the function of the gene that is closest by genomic distance.

\section{PRDM1-ATG5}

The PRDM1-ATG5 gene region has shown a significant association with increased risk of SLE at the intergenic variant rs548234 $\left(P=5.1 \times 10^{-12}, \mathrm{OR}=1.25\right)$ [109]. This variant has been shown to increase the expression of ATG5 in individuals who are homozygous for the $\mathrm{C}$ allele [109]. Since ATG5 is important for the formation of autophagosomes [110], increased expression of this gene increases autophagy, which in turn stimulates the IFN $\alpha$ and NF- $\mathrm{kB}$ pathways [109] and exacerbates the immune response. However, PRDM1 (BLIMP1) has been reported to play a role in B-cell differentiation [111], and so variants that affect PRDM1 could allow plasma cell differentiation, which further propagates hyperactive $\mathrm{B}$ cells and auto-antibody production. PRDM1 has also been reported to maintain immune tolerance and has been shown to alter DC function in female mice that lack PRDM1 expression on DCs. These mice also develop lupus-like auto-antibodies [112]. Therefore, both ATG5 and PRDM1 could potentially have causal effects for lupus. Consequently, further experiments will be required to establish whether one (or perhaps both) of these genes plays a role in genetic susceptibility to SLE.

\section{CD44-PDHX}

One trans-ancestral study (Europeans, African-Americans, and Asians) reported two intergenic SNPs between PDHX-CD44 [113]. PDHX plays a role in the pyruvate dehydrogenase complex, and CD44 is an integral cell 
membrane glycoprotein, which plays a role in cell-cell interactions and regulation of IFNY and LCK [58]. Variants in CD44 alone have been shown to be associated with SLE [58]. CD4 ${ }^{+}$and $\mathrm{CD} 8^{+} \mathrm{T}$ cells of patients with SLE have been shown to overexpress CD44, causing an influx of IFN $\gamma$, inflammation, and tissue damage [113]. This fact suggests that the intergenic associations are pointing toward $C D 44$ as a more likely candidate gene for SLE than $P D H X$.

\section{Conclusions}

In this review, we describe the key loci that have been associated with SLE to date. We have shown the importance of these genes in their most relevant related pathways (Figure 1). However, to fully understand these associations, fine-mapping studies using targeted genotyping chips, such as the ImmunoChip, will be required. These types of studies will lead to the identification of additional variants that can then be used for functional studies to elucidate the molecular mechanisms operating in lupus. The additional advantage of the ImmunoChip platform is that it allows us to look for a commonality of associations across immune-related diseases.

To date, in lupus, there have been a number of relatively small GWASs, which nonetheless have been quite successful in identifying the strongest causal genetic effects in terms of both significance, in which a $P$ value quantifies whether the difference in allele frequency between SLE cases and healthy controls is likely to occur solely by chance, and the effect size, which quantifies the amount of the observed difference between affected and unaffected individuals. However, as previously mentioned, these studies have been able to identify only approximately $10 \%$ of the genetic heritability. GWASs in SLE which are much larger than those previously undertaken will be necessary in order to expand the number of SLEassociated loci significantly. To fully explore the genetics of SLE, it is important to study high-risk groups, such as those with African or Amerindian ancestry. This will allow greater understanding of SLE across different ethnicities and will allow fine mapping of the associated loci. Such studies are currently under way.

Finally, fbuilding upon these GWASs and replication studies, functional and targeted assays (for example, next-generation sequencing) are needed. These studies enable us to identify rare variants, using methods such as next-generation sequencing, and to provide greater understanding of the biology of SLE and hence the pathogenesis of this disease. In summary, the genetics of SLE is still not fully understood, but by undertaking additional genetic studies and consequential functional assays we will obtain a much greater understanding of the etiology of the disease.

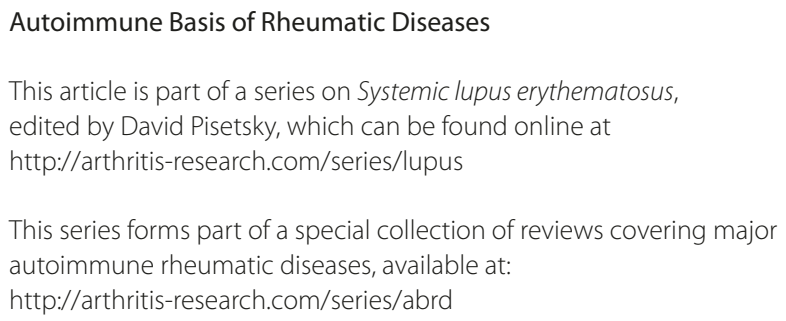

This series forms part of a special collection of reviews covering major autoimmune rheumatic diseases, available at:

http://arthritis-research.com/series/abrd

\section{Abbreviations}

$\mathrm{APC}$, antigen-presenting cell; BCR, B-cell receptor; CNV, copy number variation; CSK, cytoplasmic tyrosine kinase; DC, dendritic cell; GWAS, genome-wide association study; IC, immune complex; IFN, interferon; IL, interleukin; IP(3) R, type 1 inositol-1,2,4-triphosphate; LD, linkage disequilibrium; MHC, major histocompatibility complex; NF-KB, nuclear factor-kappa-B; OR, odds ratio; PDC, plasmacytoid dendritic cell; RA, rheumatoid arthritis; RIP, receptorinteracting protein kinase; SLE, systemic lupus erythematosus; SNP, singlenucleotide polymorphism; TCR, T-cell receptor; Th, T helper;T1D, type 1 diabetes; TLR7/9, Toll-like receptor 7/9.

\section{Competing interests}

The authors declare that they have no competing interests.

\section{Author details}

'Department of Medical and Molecular Genetics, Division of Genetics and Molecular Medicine, King's College London, Great Maze Pond, London, SE1 9RT, UK. ${ }^{2}$ Academic department of Rheumatology, Division of Immunology, Infection and Inflammatory Diseases, School of Medicine, King's College London, Great Maze Pond, London, SE1 9RT, UK.

Published: 29 May 2012

\section{References}

1. Perl A: Pathogenic mechanisms in systemic lupus erythematosus. Autoimmunity 2010, 43:1-6.

2. Johnson AE, Gordon C, Palmer RG, Bacon PA: The prevalence and incidence of systemic lupus erythematosus in Birmingham, England. Relationship to ethnicity and country of birth. Arthritis Rheum 1995, 38:551-558.

3. Lipsky PE: Systemic lupus erythematosus: an autoimmune disease of B cell hyperactivity. Nat Immunol 2001, 2:764-766.

4. Block SR, Winfield JB, Lockshin MD, D'Angelo WA, Christian CL: Studies of twins with systemic lupus erythematosus. A review of the literature and presentation of 12 additional sets. Am J Med 1975, 59:533-552.

5. Deapen D, Escalante A, Weinrib L, Horwitz D, Bachman B, Roy-Burman P, Walker A, Mack TM: A revised estimate of twin concordance in systemic lupus erythematosus. Arthritis Rheum 1992, 35:311-318.

6. Gateva V, Sandling JK, Hom G, Taylor KE, Chung SA, Sun X, Ortmann W, Kosoy R, Ferreira RC, Nordmark G, Gunnarsson I, Svenungsson E, Padyukov L, Sturfelt G, Jönsen A, Bengtsson AA, Rantapää-Dahlqvist S, Baechler EC, Brown EE, Alarcón GS, Edberg JC, Ramsey-Goldman R, McGwin G Jr., Reveille JD, Vilá LM, Kimberly RP, Manzi S, Petri MA, Lee A, Gregersen PK, et al: A large-scale replication study identifies TNIP1, PRDM1, JAZF1, UHRF1BP1 and IL10 as risk loci for systemic lupus erythematosus. Nat Genet 2009, 41:1228-1233.

7. Kerr JF, Wyllie AH, Currie AR: Apoptosis: a basic biological phenomenon with wide-ranging implications in tissue kinetics. Br J Cancer 1972, 26:239-257.

8. Salmon M, Gordon C: The role of apoptosis in systemic lupus erythematosus. Rheumatology (Oxford) 1999, 38:1177-1183.

9. Bannister KM, Hay J, Clarkson AR, Woodroffe AJ: Fc-specific reticuloendothelial clearance in systemic lupus erythematosus and glomerulonephritis. Am J Kidney Dis 1984, 3:287-292.

10. Munoz LE, Lauber K, Schiller M, Manfredi AA, Herrmann M: The role of defective clearance of apoptotic cells in systemic autoimmunity. Nat Rev Rheumatol 2010, 6:280-289.

11. Herrmann M, Voll RE, Zoller OM, Hagenhofer M, Ponner BB, Kalden JR: Impaired phagocytosis of apoptotic cell material by monocyte-derived macrophages from patients with systemic lupus erythematosus. Arthritis Rheum 1998, 41:1241-1250. 
12. Suber T, Rosen A: Apoptotic cell blebs: repositories of autoantigens and contributors to immune context. Arthritis Rheum 2009, 60:2216-2219.

13. Muñoz LE, Janko C, Grossmayer GE, Frey B, Voll RE, Kern P, Kalden JR, Schett G, Fietkau R, Herrmann M, Gaipl US: Remnants of secondarily necrotic cells fuel inflammation in systemic lupus erythematosus. Arthritis Rheum 2009, 60:1733-1742.

14. Elkon KB, Stone $\mathrm{V}$ : Type I interferon and systemic lupus erythematosus. J Interferon Cytokine Res 2011, 31:803-812.

15. Lorenz HM, Grunke M, Hieronymus T, Herrmann M, Kuhnel A, Manger B Kalden JR: In vitro apoptosis and expression of apoptosis-related molecules in lymphocytes from patients with systemic lupus erythematosus and other autoimmune diseases. Arthritis Rheum 1997, 40:306-317.

16. Nath SK, Han S, Kim-Howard X, Kelly JA, Viswanathan P, Gilkeson GS, Chen W, Zhu C, McEver RP, Kimberly RP, Alarcón-Riquelme ME, Vyse TJ, Li QZ, Wakeland EK, Merrill JT, James JA, Kaufman KM, Guthridge JM, Harley JB: A nonsynonymous functional variant in integrin-alpha(M) (encoded by ITGAM) is associated with systemic lupus erythematosus. Nat Genet 2008, 40:152-154

17. Anaya JM, Kim-Howard X, Prahalad S, Cherñavsky A, Cañas C, Rojas-Villarraga A, Bohnsack J, Jonsson R, Bolstad Al, Brun JG, Cobb B, Moser KL, James JA, Harley JB, Nath SK: Evaluation of genetic association between an ITGAM non-synonymous SNP (rs1143679) and multiple autoimmune diseases. Autoimmun Rev 2012, 11:276-280.

18. Han $S$, Kim-Howard $X$, Deshmukh $H$, Kamatani $Y$, Viswanathan $P$, Guthridge JM, Thomas K, Kaufman KM, Ojwang J, Rojas-Villarraga A, Baca V, Orozco L, Rhodes B, Choi CB, Gregersen PK, Merrill JT, James JA, Gaffney PM, Moser KL, Jacob CO, Kimberly RP, Harley JB, Bae SC, Anaya JM, Alarcón-Riquelme ME, Matsuda K, Vyse TJ, Nath SK: Evaluation of imputation-based association in and around the integrin-alpha-M (ITGAM) gene and replication of robust association between a non-synonymous functional variant within ITGAM and systemic lupus erythematosus (SLE). Hum Mol Genet 2009, 18:1171-1180

19. Hepburn AL, Mason JC, Wang S, Shepherd CJ, Florey O, Haskard DO, Davies KA: Both Fcgamma and complement receptors mediate transfer of immune complexes from erythrocytes to human macrophages under physiological flow conditions in vitro. Clin Exp Immunol 2006, 146:133-145.

20. MacPherson M, Lek HS, Prescott A, Fagerholm SC: A systemic lupus erythematosus-associated R77H substitution in the CD11b chain of the Mac-1 integrin compromises leukocyte adhesion and phagocytosis. J Biol Chem 2011, 286:17303-17310

21. Karassa FB, Trikalinos TA, loannidis JP: The Fc gamma RIIIA-F158 allele is a risk factor for the development of lupus nephritis: a meta-analysis. Kidney Int 2003, 63:1475-1482.

22. Brown EE, Edberg JC, Kimberly RP: Fc receptor genes and the systemic lupus erythematosus diathesis. Autoimmunity 2007, 40:567-581.

23. Floto RA, Clatworthy MR, Heilbronn KR, Rosner DR, MacAry PA, Rankin A, Lehner PJ, Ouwehand WH, Allen JM, Watkins NA, Smith KG: Loss of function of a lupus-associated FcgammaRllb polymorphism through exclusion from lipid rafts. Nat Med 2005, 11:1056-1058

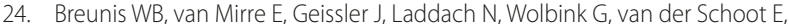
de Haas M, de Boer M, Roos D, Kuijpers TW: Copy number variation at the FCGR locus includes FCGR3A, FCGR2C and FCGR3B but not FCGR2A and FCGR2B. Hum Mutat 2009, 30:E640-E650.

25. Fanciulli M, Norsworthy PJ, Petretto E, Dong R, Harper L, Kamesh L, Heward JM, Gough SC, de Smith A, Blakemore Al, Froguel P, Owen CJ, Pearce SH, Teixeira L, Guillevin L, Cunninghame Graham DS, Pusey CD, Cook HT, Vyse TJ, Aitman TJ: FCGR3B copy number variation is associated with susceptibility to systemic, but not organ-specific, autoimmunity. Nat Genet 2007, 39:721-723.

26. Morris DL, Roberts AL, Witherden AS, Tarzi R, Barros P, Whittaker JC, Cook TH, Aitman TJ, Vyse TJ: Evidence for both copy number and allelic (NA1/NA2) risk at the FCGR3B locus in systemic lupus erythematosus. Eur J Hum Genet 2010, 18:1027-1031.

27. Weissman AM: Themes and variations on ubiquitylation. Nat Rev Mol Cell Biol 2001, 2:169-178.

28. Vereecke L, Beyaert R, van Loo G: Genetic relationships between A20/ TNFAIP3, chronic inflammation and autoimmune disease. Biochem Soc Trans 2011, 39:1086-1091.

29. Sestak AL, Furnrohr BG, Harley JB, Merrill JT, Namjou B: The genetics of systemic lupus erythematosus and implications for targeted therapy. Ann
Rheum Dis 2011, 70 Suppl 1:i37-i43.

30. Beyaert R, Heyninck K, Van Huffel S: A20 and A20-binding proteins as cellular inhibitors of nuclear factor-kappa B-dependent gene expression and apoptosis. Biochem Pharmacol 2000, 60:1143-1151.

31. Hitotsumatsu O, Ahmad RC, Tavares R, Wang M, Philpott D, Turer EE, Lee BL, Shiffin N, Advincula R, Malynn BA, Werts C, Ma A: The ubiquitin-editing enzyme $A 20$ restricts nucleotide-binding oligomerization domain containing 2-triggered signals. Immunity 2008, 28:381-390.

32. Adrianto I, Wen F, Templeton A, Wiley G, King JB, Lessard CJ, Bates JS, Hu Y, Kelly JA, Kaufman KM, Guthridge JM, Alarcón-Riquelme ME; BIOLUPUS and GENLES Networks, Anaya JM, Bae SC, Bang SY, Boackle SA, Brown EE, Petri MA, Gallant C, Ramsey-Goldman R, Reveille JD, Vila LM, Criswell LA, Edberg JC, Freedman Bl, Gregersen PK, Gilkeson GS, Jacob CO, James JA, Kamen DL, et al:: Association of a functional variant downstream of TNFAIP3 with systemic lupus erythematosus. Nat Genet 2011, 43:253-258.

33. Deng $Y$, Tsao BP: Genetic susceptibility to systemic lupus erythematosus in the genomic era. Nat Rev Rheumatol 2010, 6:683-692.

34. Musone SL, Taylor KE, Lu TT, Nititham J, Ferreira RC, Ortmann W, Shifrin N, Petri MA, Kamboh MI, Manzi S, Seldin MF, Gregersen PK, Behrens TW, Ma A, Kwok PY, Criswell LA: Multiple polymorphisms in the TNFAIP3 region are independently associated with systemic lupus erythematosus. Nat Genet 2008, 40:1062-1064.

35. Wertz IE, O'Rourke KM, Zhou H, Eby M, Aravind L, Seshagiri S, Wu P, Wiesmann C, Baker R, Boone DL, Ma A, Koonin EV, Dixit VM: De-ubiquitination and ubiquitin ligase domains of A20 downregulate NF-kappaB signalling. Nature 2004, 430:694-699.

36. Kawasaki A, Ito S, Furukawa H, Hayashi T, Goto D, Matsumoto I, Kusaoi M, Ohashi J, Graham RR, Matsuta K, Behrens TW, Tohma S, Takasaki Y, Hashimoto $H$, Sumida T, Tsuchiya N: Association of TNFAIP3 interacting protein 1, TNIP1 with systemic lupus erythematosus in a Japanese population: a casecontrol association study. Arthritis Res Ther 2010, 12:R174.

37. Oshima S, Turer EE, Callahan JA, Chai S, Advincula R, Barrera J, Shifrin N, Lee B, Benedict Yen TS, Woo T, Malynn BA, Ma A: ABIN-1 is a ubiquitin sensor that restricts cell death and sustains embryonic development. Nature 2009, 457:906-909.

38. Graham RR, Cotsapas C, Davies L, Hackett R, Lessard CJ, Leon JM, Burtt NP, Guiducci C, Parkin M, Gates C, Plenge RM, Behrens TW, Wither JE, Rioux JD, Fortin PR, Graham DC, Wong AK, Vyse TJ, Daly MJ, Altshuler D, Moser KL, Gaffney PM: Genetic variants near TNFAIP3 on 6q23 are associated with systemic lupus erythematosus. Nat Genet 2008, 40:1059-1061.

39. Agik S, Franek BS, Kumar AA, Kumabe M, Utset TO, Mikolaitis RA, Jolly M, Niewold TB: The autoimmune disease risk allele of UBE2L3 in African American patients with systemic lupus erythematosus: a recessive effect upon subphenotypes. J Rheumatol 2012, 39:73-78.

40. Moynihan TP, Cole CG, Dunham I, O'Neil L, Markham AF, Robinson PA: Finemapping, genomic organization, and transcript analysis of the human ubiquitin-conjugating enzyme gene UBE2L3. Genomics 1998, 51:124-127.

41. Nuber U, Schwarz S, Kaiser P, Schneider R, Scheffner M: Cloning of human ubiquitin-conjugating enzymes $\mathrm{UbcH} 6$ and $\mathrm{UbcH} 7$ (E2-F1) and characterization of their interaction with E6-AP and RSP5. J Biol Chem 1996, 271:2795-2800.

42. Orozco G, Eyre S, Hinks A, Bowes J, Morgan AW, Wilson AG, Wordsworth P, Steer S, Hocking L; UKRAG consortium, Thomson W, Worthington J, Barton A: Study of the common genetic background for rheumatoid arthritis and systemic lupus erythematosus. Ann Rheum Dis 2011, 70:463-468.

43. Chuang TH, Ulevitch RJ: Triad3A, an E3 ubiquitin-protein ligase regulating Toll-like receptors. Nat Immunol 2004, 5:495-502.

44. Crispin JC, Oukka M, Bayliss G, Cohen RA, Van Beek CA, Stillman IE, Kyttaris VC, Juang YT, Tsokos GC: Expanded double negative T cells in patients with systemic lupus erythematosus produce IL-17 and infiltrate the kidneys. $J$ Immunol 2008, 181:8761-8766

45. Zhou Y, Yuan J, Pan Y, Fei Y, Qiu X, Hu N, Luo Y, Lei W, Li Y, Long H, Sawalha AH, Richardson B, Lu Q: T cell CD4OLG gene expression and the production of IgG by autologous B cells in systemic lupus erythematosus. Clin Immunol 2009, 132:362-370

46. Sullivan KE, Piliero LM, Dharia T, Goldman D, Petri MA: $3^{\prime}$ polymorphisms of ETS1 are associated with different clinical phenotypes in SLE. Hum Mutat 2000, 16:49-53.

47. Hu W, Sun L, Gao J, Li Y, Wang P, Cheng Y, Pan T, Han J, Liu Y, Lu W, Zuo X, Sheng Y, Yao S, He C, Yu Z, Yin X, Cui Y, Yang S, Zhang X: Down-regulated expression of IKZF1 mRNA in peripheral blood mononuclear cells from 
patients with systemic lupus erythematosus. Rheumatol Int 2011, 31:819-822.

48. Yang W, Shen N, Ye DQ, Liu Q, Zhang Y, Qian XX, Hirankarn N, Ying D, Pan HF, Mok CC, Chan TM, Wong RW, Lee KW, Mok MY, Wong SN, Leung AM, Li XP, Avihingsanon Y, Wong CM, Lee TL, Ho MH, Lee PP, Chang YK, Li PH, Li RJ, Zhang L, Wong WH, Ng IO, Lau CS, Sham PC, Lau YL; Asian Lupus Genetics Consortium: Genome-wide association study in Asian populations identifies variants in ETS1 and WDFY4 associated with systemic lupus erythematosus. PLoS Genet 2010, 6:e1000841.

49. Bories JC, Willerford DM, Grevin D, Davidson L, Camus A, Martin P, Stehelin D, Alt FW: Increased T-cell apoptosis and terminal B-cell differentiation induced by inactivation of the Ets-1 proto-oncogene. Nature 1995, 377:635-638.

50. Eyquem S, Chemin K, Fasseu M, Chopin M, Sigaux F, Cumano A, Bories JC: The development of early and mature $B$ cells is impaired in mice deficient for the Ets-1 transcription factor. Eur J Immuno/ 2004, 34:3187-3196.

51. Wang D, John SA, Clements JL, Percy DH, Barton KP, Garrett-Sinha LA: Ets-1 deficiency leads to altered $B$ cell differentiation, hyperresponsiveness to TLR9 and autoimmune disease. Int Immuno/ 2005, 17:1179-1191.

52. Leng RX, Pan HF, Chen GM, Feng CC, Fan YG, Ye DQ, Li XP: The dual nature of Ets-1: focus to the pathogenesis of systemic lupus erythematosus. Autoimmun Rev 2011, 10:439-443.

53. Han JW, Zheng HF, Cui Y, Sun LD, Ye DQ, Hu Z, Xu JH, Cai ZM, Huang W, Zhao GP, Xie HF, Fang H, Lu QJ, Xu JH, Li XP, Pan YF, Deng DQ, Zeng FQ, Ye ZZ, Zhang XY, Wang QW, Hao F, Ma L, Zuo XB, Zhou FS, Du WH, Cheng YL, Yang $J Q$, Shen SK, Li J, et al:: Genome-wide association study in a Chinese Han population identifies nine new susceptibility loci for systemic lupus erythematosus. Nat Genet 2009, 41:1234-1237.

54. Yap WH, Yeoh E, Tay A, Brenner S, Venkatesh B: STAT4 is a target of the hematopoietic zinc-finger transcription factor Ikaros in T cells. FEBS Lett 2005, 579:4470-4478.

55. Georgopoulos K, Bigby M, Wang JH, Molnar A, Wu P, Winandy S, Sharpe A: The lkaros gene is required for the development of all lymphoid lineages. Cell 1994, 79:143-156.

56. Wojcik H, Griffiths E, Staggs S, Hagman J, Winandy S: Expression of a nonDNA-binding Ikaros isoform exclusively in B cells leads to autoimmunity but not leukemogenesis. Eur J Immunol 2007, 37:1022-1032.

57. Sanz I, Lee FE: B cells as therapeutic targets in SLE. Nat Rev Rheumato/ 2010 6:326-337.

58. Ramos PS, Williams AH, Ziegler JT, Comeau ME, Guy RT, Lessard CJ, Li H, Edberg JC, Zidovetzki R, Criswell LA, Gaffney PM, Cunninghame Graham DS, Graham RR, Kelly JA, Kaufman KM, Brown EE, Alarcón GS, Petri MA, Reveille JD, McGwin G, Vilá LM, Ramsey-Goldman R, Jacob CO, Vyse TJ, Tsao BP, Harley JB, Kimberly RP, Alarcón-Riquelme ME, Langefeld CD, Moser KL: Genetic analyses of interferon pathway-related genes reveal multiple new loci associated with systemic lupus erythematosus. Arthritis Rheum 2011, 63:2049-2057.

59. Kozyrev SV, Abelson AK, Wojcik J, Zaghlool A, Linga Reddy MV, Sanchez E, Gunnarsson I, Svenungsson E, Sturfelt G, Jönsen A, Truedsson L, Pons-Estel BA, Witte T, D'Alfonso S, Barizzone N, Danieli MG, Gutierrez C, Suarez A, Junker P, Laustrup H, González-Escribano MF, Martin J, Abderrahim H, AlarcónRiquelme ME: Functional variants in the B-cell gene BANK1 are associated with systemic lupus erythematosus. Nat Genet 2008, 40:211-216.

60. Yokoyama K, Su I, I, Tezuka T, Yasuda T, Mikoshiba K, Tarakhovsky A, Yamamoto $\mathrm{T}$ : BANK regulates $\mathrm{BCR}$-induced calcium mobilization by promoting tyrosine phosphorylation of IP(3) receptor. EMBO J 2002, 21:83-92.

61. Castillejo-López C, Delgado-Vega AM, Wojcik J, Kozyrev SV, Thavathiru E, Wu YY, Sánchez E, Pöllmann D, López-Egido JR, Fineschi S, Domínguez N, Lu R, James JA, Merrill JT, Kelly JA, Kaufman KM, Moser KL, Gilkeson G, Frostegård J, Pons-Estel BA, D'Alfonso S, Witte T, Callejas JL, Harley JB, Gaffney PM, Martin J, Guthridge JM, Alarcón-Riquelme ME: Genetic and physical interaction of the B-cell systemic lupus erythematosus-associated genes BANK1 and BLK. Ann Rheum Dis 2012, 71:136-142.

62. Huck S, Le CR, Youinou P, Zouali M: Expression of B cell receptor-associated signaling molecules in human lupus. Autoimmunity 2001, 33:213-224.

63. Xu Y, Beavitt SJ, Harder KW, Hibbs ML, Tarlinton DM: The activation and subsequent regulatory roles of Lyn and CD19 after B cell receptor ligation are independent. J Immunol 2002, 169:6910-6918.

64. Lu R, Vidal GS, Kelly JA, Delgado-Vega AM, Howard XK, Macwana SR, Dominguez N, Klein W, Burrell C, Harley IT, Kaufman KM, Bruner GR, Moser KL, Gaffney PM, Gilkeson GS, Wakeland EK, Li QZ, Langefeld CD, Marion MC, Divers J, Alarcón GS, Brown EE, Kimberly RP, Edberg JC, Ramsey-Goldman R,
Reveille JD, McGwin G Jr., Vilá LM, Petri MA, Bae SC, et al:: Genetic associations of LYN with systemic lupus erythematosus. Genes Immun 2009, 10:397-403.

65. Hibbs ML, Tarlinton DM, Armes J, Grail D, Hodgson G, Maglitto R, Stacker SA, Dunn AR: Multiple defects in the immune system of Lyn-deficient mice, culminating in autoimmune disease. Cell 1995, 83:301-311.

66. Fan Y, Tao JH, Zhang LP, Li LH, Ye DQ: Association of BLK (rs13277113, rs2248932) polymorphism with systemic lupus erythematosus: a metaanalysis. Mol Biol Rep 2011, 38:4445-4453.

67. Texido G, Su IH, Mecklenbrauker I, Saijo K, Malek SN, Desiderio S, Rajewsky K, Tarakhovsky A: The B-cell-specific Src-family kinase Blk is dispensable for B-cell development and activation. Mol Cell Biol 2000, 20:1227-1233.

68. Stone JC: Regulation of Ras in lymphocytes: get a GRP. Biochem Soc Trans 2006, 34:858-861.

69. Cunninghame Graham DS, Morris DL, Bhangale TR, Criswell LA, Syvanen AC, Ronnblom L, Behrens TW, Graham RR, Vyse TJ: Association of NCF2, IKZF1, IRF8, IFIH1, and TYK2 with systemic lupus erythematosus. PLOS Genet 2011 7:e1002341.

70. Liossis SN, Hoffman RW, Tsokos GC: Abnormal early TCR/CD3-mediated signaling events of a snRNP-autoreactive lupus T cell clone. Clin Immunol Immunopathol 1998, 88:305-310.

71. Sawla P, Hossain A, Hahn BH, Singh RP: Regulatory T cells in systemic lupus erythematosus (SLE); Role of peptide tolerance. Autoimmun Rev 2011 Oct 7. [Epub ahead of print].

72. Suárez A, López P, Gómez J, Gutiérrez C: Enrichment of CD4+ CD25high T cell population in patients with systemic lupus erythematosus treated with glucocorticoids. Ann Rheum Dis 2006, 65:1512-1517.

73. Lin SC, Chen KH, Lin CH, Kuo CC, Ling QD, Chan CH: The quantitative analysis of peripheral blood FOXP3-expressing T cells in systemic lupus erythematosus and rheumatoid arthritis patients. Eur J Clin Invest 2007, 37:987-996.

74. Remmers EF, Plenge RM, Lee AT, Graham RR, Hom G, Behrens TW, de Bakker PI, Le JM, Lee HS, Batliwalla F, Li W, Masters SL, Booty MG, Carulli JP, Padyukov L, Alfredsson L, Klareskog L, Chen WV, Amos Cl, Criswell LA, Seldin MF, Kastne DL, Gregersen PK: STAT4 and the risk of rheumatoid arthritis and systemic lupus erythematosus. N Engl J Med 2007, 357:977-986.

75. Watford WT, Hissong BD, Bream JH, Kanno Y, Muul L, O'Shea JJ: Signaling by IL-12 and IL-23 and the immunoregulatory roles of STAT4. Immunol ReV 2004, 202:139-156

76. Farrar JD, Smith JD, Murphy TL, Leung S, Stark GR, Murphy KM: Selective loss of type I interferon-induced STAT4 activation caused by a minisatellite insertion in mouse Stat2. Nat /mmunol 2000 , 1:65-69.

77. Morinobu A, Gadina M, Strober W, Visconti R, Fornace A, Montagna C, Feldman GM, Nishikomori R, O'Shea JJ: STAT4 serine phosphorylation is critical for IL-12-induced IFN-gamma production but not for cell proliferation. Proc Natl Acad Sci U S A 2002, 99:12281-12286.

78. Korman BD, Alba MI, Le JM, Alevizos I, Smith JA, Nikolov NP, Kastner DL, Remmers EF, Illei GG: Variant form of STAT4 is associated with primary Sjogren's syndrome. Genes Immun 2008, 9:267-270.

79. Martínez A, Varadé J, Márquez A, Cénit MC, Espino L, Perdigones N, Santiago $J$, Fernández-Arquero M, de la Calle H, Arroyo R, Mendoza JL, FernándezGutiérrez B, de la Concha EG, Urcelay E: Association of the STAT4 gene with increased susceptibility for some immune-mediated diseases. Arthritis Rheum 2008, 58:2598-2602.

80. Kawasaki A, Ito I, Hikami K, Ohashi J, Hayashi T, Goto D, Matsumoto I, Ito S, Tsutsumi A, Koga M, Arinami T, Graham RR, Hom G, Takasaki Y, Hashimoto H, Behrens TW, Sumida T, Tsuchiya N: Role of STAT4 polymorphisms in systemic lupus erythematosus in a Japanese population: a case-control association study of the STAT1-STAT4 region. Arthritis Res Ther 2008, 10:R113

81. Li P, Cao C, Luan H, Li C, Hu C, Zhang S, Zeng X, Zhang F, Zeng C, Li Y: Association of genetic variations in the STAT4 and IRF7/KIAA1542 regions with systemic lupus erythematosus in a Northern Han Chinese population. Hum Immunol 2011, 72:249-255.

82. Sigurdsson S, Nordmark G, Garnier S, Grundberg E, Kwan T, Nilsson O, Eloranta ML, Gunnarsson I, Svenungsson E, Sturfelt G, Bengtsson AA, Jönsen A, Truedsson L, Rantapää-Dahlqvist S, Eriksson C, Alm G, Göring HH, Pastinen T, Syvänen AC, Rönnblom L: A risk haplotype of STAT4 for systemic lupus erythematosus is over-expressed, correlates with anti-dsDNA and shows additive effects with two risk alleles of IRF5. Hum Mol Genet 2008, 17:2868-2876. 
83. Aksoy R, Duman T, Keskin O, Duzgun N: No association of PTPN22 R620 W gene polymorphism with rheumatic heart disease and systemic lupus erythematosus. Mol Biol Rep 2011, 38:5393-5396.

84. Criswell LA, Pfeiffer KA, Lum RF, Gonzales B, Novitzke J, Kern M, Moser KL, Begovich AB, Carlton VE, Li W, Lee AT, Ortmann W, Behrens TW, Gregersen PK: Analysis of families in the multiple autoimmune disease genetics consortium (MADGC) collection: the PTPN22 620W allele associates with multiple autoimmune phenotypes. Am J Hum Genet 2005, 76:561-571.

85. Lea WW, Lee YH: The association between the PTPN22 C1858T polymorphism and systemic lupus erythematosus: a meta-analysis update. Lupus 2011, 20:51-57.

86. Begovich AB, Carlton VE, Honigberg LA, Schrodi SJ, Chokkalingam AP, Alexander HC, Ardlie KG, Huang Q, Smith AM, Spoerke JM, Conn MT, Chang M, Chang SY, Saiki RK, Catanese JJ, Leong DU, Garcia VE, McAllister LB, Jeffery DA, Lee AT, Batliwalla F, Remmers E, Criswell LA, Seldin MF, Kastner DL, Amos $\mathrm{Cl}$, Sninsky JJ, Gregersen PK: A missense single-nucleotide polymorphism in a gene encoding a protein tyrosine phosphatase (PTPN22) is associated with rheumatoid arthritis. Am J Hum Genet 2004, 75:330-337.

87. Bottini N, Musumeci L, Alonso A, Rahmouni S, Nika K, Rostamkhani M, MacMurray J, Meloni GF, Lucarelli P, Pellecchia M, Eisenbarth GS, Comings D, Mustelin T: A functional variant of lymphoid tyrosine phosphatase is associated with type I diabetes. Nat Genet 2004, 36:337-338.

88. Vang T, Congia M, Macis MD, Musumeci L, Orrú V, Zavattari P, Nika K, Tautz L, Taskén K, Cucca F, Mustelin T, Bottini N: Autoimmune-associated lymphoid tyrosine phosphatase is a gain-of-function variant. Nat Genet 2005, 37:1317-1319

89. Gourh P, Arnett FC, Tan FK, Assassi S, Divecha D, Paz G, McNearney T, Draeger $\mathrm{H}$, Reveille JD, Mayes MD, Agarwal SK: Association of TNFSF4 (OX40L) polymorphisms with susceptibility to systemic sclerosis. Ann Rheum Dis 2010, 69:550-555.

90. Cunninghame Graham DS, Graham RR, Manku H, Wong AK, Whittaker JC, Gaffney PM, Moser KL, Rioux JD, Altshuler D, Behrens TW, Vyse TJ: Polymorphism at the TNF superfamily gene TNFSF4 confers susceptibility to systemic lupus erythematosus. Nat Genet 2008, 40:83-89.

91. Chang YK, Yang W, Zhao M, Mok CC, Chan TM, Wong RW, Lee KW, Mok MY, Wong SN, Ng IO, Lee TL, Ho MH, Lee PP, Wong WH, Lau CS, Sham PC, Lau YL: Association of BANK1 and TNFSF4 with systemic lupus erythematosus in Hong Kong Chinese. Genes Immun 2009, 10:414-420.

92. Gramaglia I, Jember A, Pippig SD, Weinberg AD, Killeen N, Croft M: The OX40 costimulatory receptor determines the development of CD4 memory by regulating primary clonal expansion. J Immunol 2000, 165:3043-3050.

93. Farres MN, Al-Zifzaf DS, Aly AA, Abd Raboh NM: OX40/OX40L in systemic lupus erythematosus: association with disease activity and lupus nephritis. Ann Saudi Med 2011, 31:29-34.

94. Fernando MM, Stevens CR, Sabeti PC, Walsh EC, McWhinnie AJ, Shah A, Green T. Rioux JD, Vyse TJ: Identification of two independent risk factors for lupus within the MHC in United Kingdom families. PLoS Genet 2007, 3:e192.

95. International Consortium for Systemic Lupus Erythematosus Genetics (SLEGEN), Harley JB, Alarcón-Riquelme ME, Criswell LA, Jacob CO, Kimberly RP, Moser KL, Tsao BP, Vyse TJ, Langefeld CD, Nath SK, Guthridge JM, Cobb BL, Mirel DB, Marion MC, Williams AH, Divers J, Wang W, Frank SG, Namjou B, Gabriel SB, Lee AT, Gregersen PK, Behrens TW, Taylor KE, Fernando M, Zidovetzki R, Gaffney PM, Edberg JC, Rioux JD, Ojwang JO, et al.: Genomewide association scan in women with systemic lupus erythematosus identifies susceptibility variants in ITGAM, PXK, KIAA1542 and other loci. Nat Genet 2008, 40:204-210

96. Fernando MM, Freudenberg J, Lee A, Morris DL, Boteva L, Rhodes B, GonzalezEscribano MF, Lopez-Nevot MA, Navarra SV, Gregersen PK, Martin J; IMAGEN, Vyse TJ: Transancestral mapping of the MHC region in systemic lupus erythematosus identifies new independent and interacting loci at MSH5, HLA-DPB1 and HLA-G. Ann Rheum Dis 2012, 71:777-784.

97. Baechler EC, Batliwalla FM, Karypis G, Gaffney PM, Ortmann WA, Espe KJ Shark KB, Grande WJ, Hughes KM, Kapur V, Gregersen PK, Behrens TW: Interferon-inducible gene expression signature in peripheral blood cells of patients with severe lupus. Proc Natl Acad Sci U S A 2003, 100:2610-2615.

98. Ronnblom $\mathrm{L}$ : The type I interferon system in the etiopathogenesis of autoimmune diseases. Ups J Med Sci 2011, 116:227-237.

99. Salloum R, Niewold TB: Interferon regulatory factors in human lupus pathogenesis. Trans/ Res 2011, 157:326-331.
100. Feng D, Stone RC, Eloranta ML, Sangster-Guity N, Nordmark G, Sigurdsson S, Wang C, Alm G, Syvänen AC, Rönnblom L, Barnes BJ: Genetic variants and disease-associated factors contribute to enhanced interferon regulatory factor 5 expression in blood cells of patients with systemic lupus erythematosus. Arthritis Rheum 2010, 62:562-573.

101. Cunninghame Graham DS, Manku H, Wagner S, Reid J, Timms K, Gutin A, Lanchbury JS, Vyse TJ: Association of IRF5 in UK SLE families identifies a variant involved in polyadenylation. Hum Mol Genet 2007, 16:579-591.

102. Robinson T, Kariuki SN, Franek BS, Kumabe M, Kumar AA, Badaracco M, Mikolaitis RA, Guerrero G, Utset TO, Drevlow BE, Zaacks LS, Grober JS, Cohen LM, Kirou KA, Crow MK, Jolly M, Niewold TB: Autoimmune disease risk variant of IFIH1 is associated with increased sensitivity to IFN-alpha and serologic autoimmunity in lupus patients. I Immuno/ 2011, 187:1298-1303.

103. Smyth DJ, Cooper JD, Bailey R, Field S, Burren O, Smink LJ, Guja C, IonescuTirgoviste C, Widmer B, Dunger DB, Savage DA, Walker NM, Clayton DG, Todd $J A:$ A genome-wide association study of nonsynonymous SNPs identifies a type 1 diabetes locus in the interferon-induced helicase (IFIH1) region. Nat Genet 2006, 38:617-619.

104. Sutherland A, Davies J, Owen CJ, Vaikkakara S, Walker C, Cheetham TD, James RA, Perros P, Donaldson PT, Cordell HJ, Quinton R, Pearce SH: Genomic polymorphism at the interferon-induced helicase (IFIH1) locus contributes to Graves' disease susceptibility. J Clin Endocrinol Metab 2007 92:3338-3341.

105. Genetic Analysis of Psoriasis Consortium \& the Wellcome Trust Case Control Consortium 2, Strange A, Capon F, Spencer CC, Knight J, Weale ME, Allen MH, Barton A, Band G, Bellenguez C, Bergboer JG, Blackwell JM, Bramon E, Bumpstead SJ, Casas JP, Cork MJ, Corvin A, Deloukas P, Dilthey A, Duncanson A,Edkins S, Estivill X, Fitzgerald O, Freeman C, Giardina E, Gray E, Hofer A, Hüffmeier U, Hunt SE, Irvine AD, Jankowski J, et al:: A genome-wide association study identifies new psoriasis susceptibility loci and an interaction between HLA-C and ERAP1. Nat Genet 2010, 42:985-990.

106. Järvinen TM, Hellquist A, Koskenmies S, Einarsdottir E, Koskinen LL, Jeskanen L, Berglind L, Panelius J, Hasan T, Ranki A, Kere J, Saarialho-Kere U: Tyrosine kinase 2 and interferon regulatory factor 5 polymorphisms are associated with discoid and subacute cutaneous lupus erythematosus. Exp Dermatol 2010, 19:123-131.

107. Ishizaki M, Akimoto T, Muromoto R, Yokoyama M, Ohshiro Y, Sekine Y, Maeda $H$, Shimoda K, Oritani K, Matsuda T: Involvement of tyrosine kinase-2 in both the IL-12/Th1 and IL-23/Th17 axes in vivo. J Immunol 2011 187:181-189.

108. Tao JH, Zou YF, Feng XL, Li J, Wang F, Pan FM, Ye DQ: Meta-analysis of TYK2 gene polymorphisms association with susceptibility to autoimmune and inflammatory diseases. Mol Biol Rep 2011, 38:4663-4672.

109. Zhou XJ, Lu XL, Lv JC, Yang HZ, Qin LX, Zhao MH, Su Y, Li ZG, Zhang H: Genetic association of PRDM1-ATG5 intergenic region and autophagy with systemic lupus erythematosus in a Chinese population. Ann Rheum Dis 2011, 70:1330-1337.

110. Kuma A, Hatano M, Matsui M, Yamamoto A, Nakaya H, Yoshimori T, Ohsumi Y, Tokuhisa T, Mizushima N: The role of autophagy during the early neonatal starvation period. Nature 2004, 432:1032-1036.

111. Garaud JC, Schickel JN, Blaison G, Knapp AM, Dembele D, Ruer-Laventie J, Korganow AS, Martin T, Soulas-Sprauel P, Pasquali JL: B cell signature during inactive systemic lupus is heterogeneous: toward a biological dissection of lupus. PLoS One 2011, 6:e23900

112. Kim SJ, Zou YR, Goldstein J, Reizis B, Diamond B: Tolerogenic function of Blimp-1 in dendritic cells. J Exp Med 2011, 208:2193-2199.

113. Lessard CJ, Adrianto I, Kelly JA, Kaufman KM, Grundahl KM, Adler A, Williams AH, Gallant CJ; Marta E. Alarcón-Riquelme on behalf of the BIOLUPUS and GENLES Networks, Anaya JM, Bae SC, Boackle SA, Brown EE, Chang DM, Criswell LA, Edberg JC, Freedman BI, Gregersen PK, Gilkeson GS, Jacob CO, James JA, Kamen DL, Kimberly RP, Martin J, Merrill JT, Niewold TB, Park SY, Petri MA, Pons-Estel BA, et al.: Identification of a systemic lupus erythematosus susceptibility locus at $11 \mathrm{p} 13$ between PDHX and CD44 in a multiethnic study. Am J Hum Genet 2011, 88:83-91.

doi:10.1186/ar3844

Cite this article as: Guerra SG, et al: The genetics of lupus: a functional perspective. Arthritis Research \& Therapy 2012, 14:211. 